Check for updates

Montreal

Cite this as: BMJ 2020;370:m3787 http://dx.doi.org/10.1136/bmj.m3787 Published: 29 September 2020

\title{
Covid-19: Turkey cracks down on doctors who doubt official figures
}

\section{Owen Dyer}

Doctors in Turkey who post information about local covid-19 cases on social media are facing harassment and criminal charges from authorities anxious to hide the extent of the pandemic's spread in the country, the Turkish Medical Association has said.

As cases and deaths mount after the government's summer shift to a "normalisation" policy, tension is growing because of discrepancies between the official counts and reports from professionals on the ground.

Tension is growing too between the government and the medical profession. This month, as doctors around the country wore black ribbons to commemorate colleagues lost to the pandemic, President Recep Erdoğan's coalition partner Devlet Bahçeli, leader of the Nationalist Movement Party, called for the Turkish Medical Association to be outlawed and its leadership prosecuted.

"The Turkish Medical Association is as dangerous as coronavirus and is disseminating threats," said Bahçeli on Twitter. "The medical association which claims the name 'Turkish' should immediately be shut down. Legal action must be taken against its executives."

Doctors held a week long protest from 13 to 20 September to commemorate Turkish health workers who died from covid-19, carrying placards criticising the government's pandemic response. One said, "You can't handle it. We're burning out.” Bahçeli called the protest a "treacherous plot."

The authorities have targeted local leaders in the medical association since the pandemic began, with several ordered to surrender their passports and check in regularly at police stations. In March Özgür Deniz Değer, co-chair of the medical chamber of the eastern city of Van, was summoned by police after he criticised the government in an interview for not including political prisoners in a pandemic release scheme for detainees.

In May, after tweeting his doubts about the government's health worker death toll, he was charged under a law that carries up to a four year sentence for "creating fear and panic among the people.” The charges were later dropped, but the threat led Değer to self-censor, he told Science magazine.

The co-chair of Şanlıurfa Medical Chamber, Ömer Melik, and its secretary general, Osman Yüksekyayla, have twice been detained and questioned by police. The first time, Melik had posted the number of local cases on the chamber's Twitter account. The second time, the chamber had raised concerns over deaths of health worker and lack of personal protective equipment.

In April, Kayıhan Pala, a public health expert at Uludağ University, in the city of Bursa, was charged under the law against spreading panic, after a complaint from the governor of Bursa province. In a local media interview Pala had accused the government of understating covid-19 cases and deaths. The charges were eventually dropped after a public outcry.

Scepticism over official covid-19 figures is widespread among Turkey's doctors. “The numbers of just one city, or just one or two medical chambers, are almost equal to the [official] numbers for the whole country," physician Halis Yerlikaya told Reuters at a hospital in Diyarbakir.

The government does not release regional figures and has removed cause of death from public death registers. But the health minister, Fahrettin Koca, denied hiding cases at a press conference earlier this month, noting that official numbers were now rising fast.

The Turkish Medical Association has long been a target of Erdoğan's government. Its entire central committee was arrested in 2018 after it criticised a Turkish military incursion into Syria. Eleven members, including its chair, Sinan Adryaman, received prison sentences of 20 months or more. ${ }^{1}$ These remain under appeal, and the doctors are currently at liberty.

More than 3300 doctors were forced out of their jobs under a decree promulgated after the 2016 coup. The government later passed a law requiring all new medical graduates to obtain security clearance before working. ${ }^{2}$ The law was struck down by the courts but is being rewritten. The harsh environment has fuelled an increasing medical brain drain to other countries, according to the medical association. ${ }^{34}$

Dyer 0 . Turkish doctors protest as 11 of their leaders are imprisoned. BMJ 2019;365:12280. doi: 10.1136/bmj.12280 pmid: 31113796

2 Stockholm Centre for Freedom. Turkish government reluctant to assign 1100 newly graduated medical doctors on basis of security checks. 8 Dec 2017. https://stockholmcf.org/turkish-govt-reluctant-to-assign-1100-newlygraduated-medical-doctors-on-basis-of-security-checks.

3 Karabat A. Turkish doctors face far-reaching new police and intelligence checks. Middle East Eye. 15 Nov 2018. https://www.middleeasteye.net/news/turkish-doctors-face-far-reaching-new-police-and-intelligencechecks.

4 Why are doctors leaving Turkey? Inside Turkey. 6 Jan 2020. https://insideturkey.news/2020/01/06/why-are-doctors-leaving-turkey.

This article is made freely available for use in accordance with BMJ's website terms and conditions for the duration of the covid-19 pandemic or until otherwise determined by BMJ. You may use, download and print the article for any lawful, non-commercial purpose (including text and data mining) provided that all copyright notices and trade marks are retained. 